\section{Orchard Cooling with Pulsed Overtree Irrigation to Prevent Solar Injury and Improve Fruit Quality of 'Jonagold' Apples}

\author{
P. Parchomchuk and M. Meheriuk \\ Agriculture and Agri-Food Canada Research Centre, Summerland, BC VOH \\ 1Z0, Canada
}

Additional index words. evaporative cooling, sunburn, Malus domestica

\begin{abstract}
Pulsed application of overtree irrigation for evaporative cooling of 'Jonagold' apples (Malus domestica Borkh.) reduced visible solar injury by $15.8 \%$ (1991) and $9.4 \%$ (1992). Maximum fruit surface temperature was reduced by $8.1^{\circ} \mathrm{C}$ on a day when the average surface mean of nonsprayed fruit rose to $45.6^{\circ} \mathrm{C}$. Air heated more slowly than the exposed fruit surface and was cooled only 1 to $2^{\circ} \mathrm{C}$ by overtree irrigation. Cooling did not affect fruit size, firmness, or redness but reduced soluble solids concentration and increased titratable acidity. Storage breakdown was unaffected in the first year but was reduced by $6.0 \%$ in the second year.
\end{abstract}

Apple growers in the southern interior of British Columbia recently began producing cultivars, such as 'Gala', 'Jonagold', and 'Fuji', in high-density orchard plantings. However, these cultivars are prone to solar injury (SI) under the hot and semiarid climatic conditions of this region. The injury appears to be more prevalent in high-density plantings because of a greater degree of fruit exposure than in conventional (lower density) planting systems.

Solar injury results from tissue damage caused by radiant heating of the fruit surface when directly exposed to sunlight (Atkinson, 1971). On a bright, sunny day surface temperature $\left(\mathrm{t}_{\mathrm{s}}\right)$ of an apple may exceed $50^{\circ} \mathrm{C}$ even though the air is 10 to $15^{\circ} \mathrm{C}$ cooler (Unrath, 1975). The critical $t_{s}$ at which SI is initiated or the cumulative temperature effects are unknown, but Bergh et al. (1980) observed SI on several apple cultivars when $\mathrm{t}_{\mathrm{s}}$ exceeded $50^{\circ} \mathrm{C}$ for only a single day. Susceptibility of apples to SI varies with cultivar and rootstock (Bergh et al., 1980) and the extent of exposure to direct sunlight (Atkinson, 1971).

The use of overtree irrigation systems to provide evaporative cooling for improving fruit quality or preventing SI has been studied by several researchers. Unrath $(1972,1975)$, using overtree sprinklers to apply water at 2.5 $\mathrm{mm} \cdot \mathrm{h}^{-1}$ when air temperature $\left(\mathrm{t}_{\mathrm{a}}\right)$ exceeded 28 ${ }^{\circ} \mathrm{C}$ or $\mathrm{t}_{\mathrm{s}}$ exceeded $35^{\circ} \mathrm{C}$, reported improvements in red pigmentation, soluble solids concentration (SSC), and size of 'Delicious' apples. Williams (1993) noted an improvement in grade pack-out for 'Delicious' subjected to evaporative cooling. Recasens et al. (1988) reported larger fruit and higher SSC for 'Jonee'

Received for publication 6 Nov. 1995. Accepted for publication 17 Mar. 1996. Contribution no. 953. The cost of publishing this paper was defrayed in part by the payment of page charges. Under postal regulations, this paper therefore must be hereby marked advertisement solely to indicate this fact. and 'Golden Smoothee' apples when water was applied at $3 \mathrm{~mm} \cdot \mathrm{h}^{-1}$ whenever $\mathrm{t}_{\mathrm{a}}$ exceeded $32{ }^{\circ} \mathrm{C}$.

Kotze et al. (1988) reported a 50\% reduction in the incidence of SI on spray-cooled 'Granny Smith' and 'Golden Delicious' apples. They applied water at $6 \mathrm{~mm} \cdot \mathrm{h}^{-1}$ through a system of microjet sprinklers whenever $\mathrm{t}_{\mathrm{a}}$ exceeded $28^{\circ} \mathrm{C}$. The cycle of a 2 -min on pulse was followed by either 6 or 9 min off until $t_{a}$ decreased below the set value. Provided that the cycle time is short enough to maintain a wetted fruit surface during the off period, pulsed application of spray cooling is preferred to continuous operation since the water delivery rate can by minimized by using the same water source to cycle through several orchard zones in sequence.

In this study, we investigated the effect of pulsed application of water on $t_{s}$ and incidence of SI in 'Jonagold' apples. The effects of cooling on red pigment development, SSC, fruit size, acidity, and storage disorders also were evaluated.

\section{Materials and Methods}

This study was conducted during 1991 and 1992 in a 1-ha planting of 5-year-old 'Jonagold' trees on M.26 rootstock. The trees were planted in double-row beds with $1.5 \mathrm{~m}$ between rows and 3.6-malleyways between beds. Trees were spaced $1.5 \mathrm{~m}$ within rows. The site was divided into 8 blocks, each $30 \mathrm{~m}$ long $\times 3$ doublerow beds wide. The planting was irrigated by drip emitters along each tree row.

Microsprinklers with a $40-\mathrm{L} \cdot \mathrm{h}^{-1}$ discharge rate were installed $0.30 \mathrm{~m}$ above the tree canopy at 3.6-m intervals along the center of each double-row bed to give a precipitation rate of $\approx 2 \mathrm{~mm} \cdot \mathrm{h}^{-1}$. One-half of each block was evaporatively cooled and the adjacent half was used as a control.

Other studies have relied on $t_{a}$ or $t_{s}$ to activate their spray cooling systems. However, air heats more slowly than an apple (Parchomchuk et al., 1991) and apples are prone to decay when thermocouples are inserted to measure skin temperature. To overcome these problems, an artificial sensor was used to simulate the thermal response of an apple surface. The sensor was constructed by positioning a copper-constantan thermocouple against the inner wall of an opaque $250-\mathrm{mL}$ polyethylene cup $(5.5 \mathrm{~cm}$ diameter $\times 10 \mathrm{~cm}$ height $\times 1 \mathrm{~mm}$ wall thickness). The cup was filled with a green gel prepared by dissolving $15 \mathrm{~g}$ of agar granules in $1.0 \mathrm{~L}$ of near-boiling water and adding $5 \mathrm{~mL}$ of green food coloring. Temperatures measured by thermocouples on the inner surface of the plastic cup were similar to those measured beneath the skin of apples (data not shown).

Sensors were positioned in a fully exposed location above the tree canopy within $1.0 \mathrm{~m}$ of a sprinkler and activated a pulsed cooling cycle of 2 min on and 4 min off when their temperature rose above $30^{\circ} \mathrm{C}(1991)$ or $32^{\circ} \mathrm{C}$ (1992). The intermittent cycling continued until the temperature decreased below $28^{\circ} \mathrm{C}$. The system was operated from 5 July in 1991 and from 14 July in 1992 until the fruit were harvested.

Surface temperatures of one cooled and one noncooled fruit in each of three blocks were measured to within $\pm 0.5^{\circ} \mathrm{C}$ by 0.6 - $\mathrm{mm}$ diameter copper-constantan thermocouples inserted just beneath the skin of the most exposed surface. Air temperature was measured by shaded thermocouples placed within the tree canopy $1.0 \mathrm{~m}$ above ground. Temperatures were recorded with a datalogger at $15-$ min intervals between 0900 and 1900 HR daily and at 15-s intervals during spray cooling cycles.

Fruit were harvested on 8 Oct. 1991 and 22 Sept. 1992. Samples of 200 to 300 apples for evaluation of SI and fruit quality consisted of all the fruit harvested from two or three randomly selected trees located near the middle portion of each plot. The severity of SI on apples from each of the 16 plots (eight blocks $x$ two treatments) was visually rated as: none $=$ no evidence of surface discoloration; slight $=$ surface discoloration noticeable upon close examination; moderate $=$ surface discoloration readily noticeable; or severe $=$ solid brown or black areas.

Subsamples of 15 fruit from each plot were assessed for average fruit weight, proportion of red skin color, flesh firmness, SSC, and titratable acidity (TA). Additional samples of $\approx 65$ fruit were placed in $0{ }^{\circ} \mathrm{C}$ air storage for 120 days. Upon removal from cold storage, 15 fruit were assessed for flesh firmness, while the remaining 50 fruit were ripened for 7 days at $20^{\circ} \mathrm{C}$ and evaluated for disorders.

Red skin pigmentation was estimated visually. Flesh firmness was determined with a Magness-Taylor penetrometer (11.1-mm tip) using two readings from opposite sides of the fruit from which the skin had been pared. SSC and TA in the composited juice sample were measured by refractometry and titration (endpoint $\mathrm{pH} 8.1$ ), respectively. Statistical analysis was performed using SAS's GLM procedure (SAS Inst., Cary, N.C.) as a randomized block design. 


\section{Results and Discussion}

Fruit surface temperature. Maximum $\mathrm{t}_{\mathrm{s}}$ recorded for the 'Jonagold' apples was $48.2{ }^{\circ} \mathrm{C}$ in 1991 and $45.9^{\circ} \mathrm{C}$ in 1992 , but daily maximums changed with weather conditions. Significant $(P<0.05)$ differences in maximum $\mathrm{t}_{\mathrm{s}}$ of cooled and noncooled apples occurred in both years, especially when $\mathrm{t}_{\mathrm{s}}$ of noncooled fruit exceeded $35^{\circ} \mathrm{C}$ (Fig. 1). Surface temperature of cooled fruit rose above the setpoint $\left(30^{\circ} \mathrm{C}\right.$ in $1991,32^{\circ} \mathrm{C}$ in 1992$)$, but at a slower rate than for noncooled fruit. Average maximum daily $t_{\mathrm{s}}$ of cooled and noncooled fruit differed by as much as $6.3{ }^{\circ} \mathrm{C}$ in 1991 and 8.1 ${ }^{\circ} \mathrm{C}$ in 1992 . The reduction in $\mathrm{t}_{\mathrm{s}}$ obtained by pulsed application of cooling water approached the $9{ }^{\circ} \mathrm{C}$ reduction recorded by Evans et al. (1993) for continuous cooling at the same precipitation rate used in our study. However, our pulsing procedure discharged only onethird as much water as continuous application.

In most cases, $t_{\mathrm{s}}$ of the artificial fruit sensors used to initiate and terminate overtree irrigation were maintained at or below the setpoint (data not shown). The continued temperature rise above the setpoint of apples suggests lower precipitation rates on the apples than on the sensors. The monitored apples, located at 1.0-m height within the tree canopy, but fully exposed to afternoon sunlight, were less favorably exposed to the cooling water than the sensors, which were located above the tree canopy and, in most cases, closer to a sprinkler. The preferentially cooled sensors may have triggered termination of the cooling water cycles before the actual fruit had been cooled to the setpoint. In retrospect, it would have been more desirable to place the control sensors within the tree canopy where they would receive the same exposure to cooling water and sunlight as the real fruit.

Air temperature. Maximum $\mathrm{t}_{\mathrm{s}}$ exceeded maximum $\mathrm{t}_{\mathrm{a}}$ by as much as $10{ }^{\circ} \mathrm{C}$. Despite close correlation between maximum daily $t_{a}$ and $\mathrm{t}_{\mathrm{s}}$ in noncooled plots $\left(r^{2}=0.89\right)$ over the season, temperature patterns throughout the day were not so closely related. The fruit surface heated more rapidly than air and started to $\operatorname{cool} 2$ to $3 \mathrm{~h}$ before the maximum $\mathrm{t}_{\mathrm{a}}$ had been reached so that $t_{a}$ and $t_{s}$ differed by as much as $15^{\circ} \mathrm{C}$ in the early afternoon (Fig. 2). In 1991, average $\mathrm{t}_{\mathrm{a}}$ varied from 20 to $29^{\circ} \mathrm{C}$ at the time that average fruit $\mathrm{t}_{\mathrm{s}}$ had reached $30^{\circ} \mathrm{C}$. The poor correlation between $\mathrm{t}_{\mathrm{a}}$ and $\mathrm{t}_{\mathrm{s}}$ confirms that $\mathrm{t}_{\mathrm{a}}$ is not a reliable indicator for activating an irrigation cooling system. Furthermore, the limited decrease in $\mathrm{t}_{\mathrm{a}}$ in the cooled plots (Fig. 1) indicates that cooling systems controlled by air temperature would continue to apply water after the desired cooling of the fruit had been achieved.

Solar injury. Evidence of SI was present on $>35 \%$ of the noncooled fruit in 1991 and 1992, but mostly in the slight category (Table 1). Cooling did not reduce the incidence of slight SI, but it did reduce the amount of moderate SI. Severe SI was low in both years but was reduced by cooling in 1991 . Despite substantial cooling of the fruit surface from overtree application of water, the net effect on SI was a

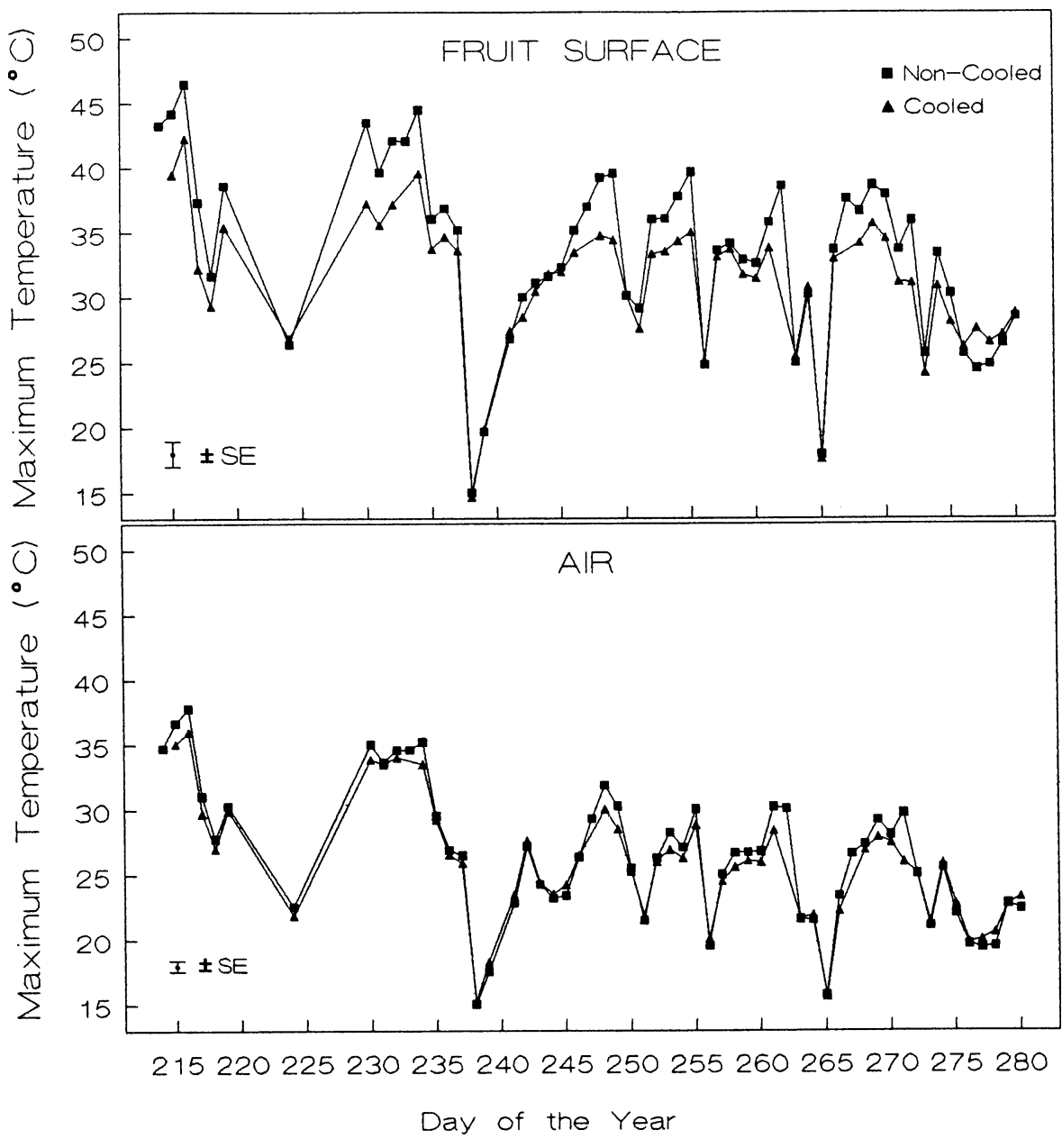

Fig. 1. Daily maximum temperature of fruit surfaces and air in cooled and noncooled plots during 1991 (e.g., Day $215=3$ Aug., Day $280=5$ Oct.).

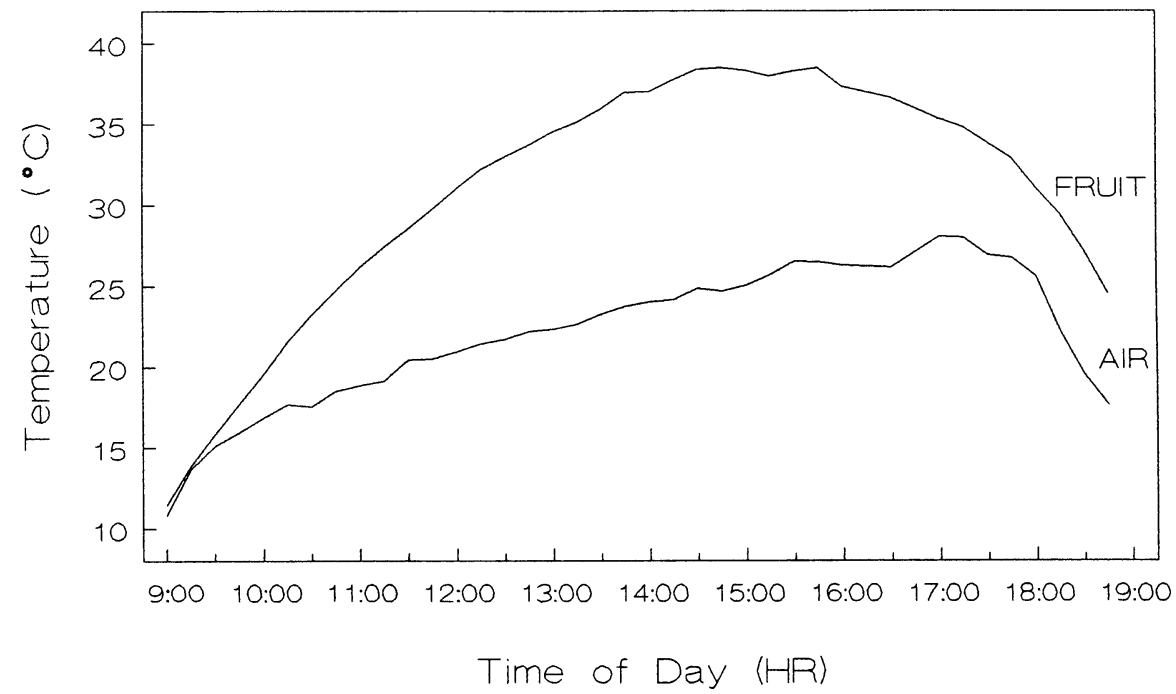

Fig. 2. Fruit surface and air temperature in a noncooled plot on a warm sunny day (26 Sept. 1991).

$5 \%$ to $8 \%$ reduction in moderately to severely injured fruit. In view of this modest reduction, the economic benefit of installing an overtree cooling system solely to prevent the disorder is questionable. Nevertheless, it might prove feasible for apple cultivars with a high return.

The poor effectiveness of 2-min-on, 4min-off pulses in reducing SI of 'Jonagold' apples in this study may be attributable to interception and diversion of the applied water by tree foliage, which resulted in variable amounts of water impinging on fruit surfaces at various locations within the tree canopy. Longer run times or higher application rates than those used in this study may be required for the cooling water to penetrate through the 


\section{Crop Production}

tree canopy and provide more complete and uniform wetting of fruit surfaces.

Fruit quality. Contrary to reports of improved redness, fruit size, and SSC in studies with other cultivars, pulsed cooling of 'Jonagold' apples in our study had no effect on average fruit weight, red pigment development, or firmness in either year (data not shown) but reduced SSC in 1992 (Table 2). Cooling resulted in higher TA in 1991 and less storage breakdown in 1992. Although Unrath (1975) reported improved redness of 'Delicious' apples when cooling was started in early June, the lack of effect on 'Jonagold' in our study could be related to the later starting date of cooling, differences in the way that cultivars respond to cooling, or to differences in climatic conditions. For instance, cool nights conducive to red pigment development are common in the apple-growing regions of British Columbia where this study was conducted. Thus, the potential for evaporative cooling to enhance redness or other fruit quality characteristics was low in this region compared to other regions where less favorable climatic conditions exist.

\section{Literature Cited}

Atkinson, J.D. 1971. Sunburn, p. 168-169. In: J.D. Atkinson (ed.). Diseases of tree fruits in New Zealand. Govt. Printer, Wellington, New Zealand.

Bergh, O., J. Franken, E.J.Zyl, F. Van Kloppers, and

Table 1. Effect of cooling by overtree irrigation on the incidence and severity of solar injury in 'Jonagold' apple.

\begin{tabular}{|c|c|c|c|c|c|c|c|c|}
\hline \multirow[b]{3}{*}{ Cooling } & \multicolumn{8}{|c|}{ Incidence of solar injury (\%) } \\
\hline & \multicolumn{2}{|c|}{ Slight } & \multicolumn{2}{|c|}{ Moderate } & \multicolumn{2}{|c|}{ Severe } & \multicolumn{2}{|c|}{ Total } \\
\hline & 1991 & 1992 & 1991 & 1992 & 1991 & 1992 & 1991 & 1992 \\
\hline No & 26.1 & 26.7 & 12.4 & 7.5 & 0.6 & 2.2 & 39.1 & 36.4 \\
\hline Yes & 18.8 & 21.8 & 4.4 & 3.4 & 0.1 & 1.6 & 23.3 & 26.8 \\
\hline Significance & NS & NS & $* *$ & $* *$ & $*$ & NS & $*$ & $*$ \\
\hline
\end{tabular}

$\overline{\text { Ns, }, * * *}$ Nonsignificant or significant at $P \leq 0.05$ or 0.01 , respectively.

Table 2. Effect of overtree evaporative cooling on fruit quality and breakdown of 'Jonagold' apple. ${ }^{2}$

\begin{tabular}{|c|c|c|c|c|c|c|}
\hline \multirow[b]{2}{*}{ Cooling } & \multicolumn{2}{|c|}{$\begin{array}{c}\text { Soluble solids } \\
\text { concn }(\%)\end{array}$} & \multicolumn{2}{|c|}{$\begin{array}{c}\text { Titratable acidity } \\
(\% \text { malic acid })\end{array}$} & \multicolumn{2}{|c|}{$\begin{array}{c}\text { Breakdown } \\
\text { incidence }(\%)\end{array}$} \\
\hline & 1991 & 1992 & 1991 & 1992 & 1991 & 1992 \\
\hline No & 15.5 & 16.2 & 0.55 & 0.49 & 21.3 & 8.9 \\
\hline Yes & 15.4 & 15.3 & 0.60 & 0.49 & 27.0 & 2.9 \\
\hline Significance & NS & $* *$ & $*$ & NS & NS & $*$ \\
\hline
\end{tabular}

${ }^{z}$ Values at harvest, except for breakdown, which was evaluated after 120 days at $0{ }^{\circ} \mathrm{C}+7$ days at $20{ }^{\circ} \mathrm{C}$. ns, *,**Nonsignificant or significant at $P \leq 0.05$ or 0.01 , respectively.

A. Dempers. 1980. Sunburn on apples-Preliminary results of an investigation conducted during the 1978/79 season. Deciduous Fruit Grower 30(1):8-22.

Evans, R.G., M.W. Kroeger, and M.O. Mahan. 1993. Evaporative cooling of apples by overtree sprinkling. Amer. Soc. Agr. Eng. Paper 932060.

Kotze, W.A.G., J.A. Carreira, O. Beukes, and A.V. Redelinghuys. 1988. Effect of evaporative cooling on the growth, yield and fruit quality of apples. Deciduous Fruit Grower 38:20-24.

Parchomchuk, P., H. Bush, and E.J. Hogue. 1991. Orchard spray cooling to reduce apple fruit sur- face temperatures. B.C. Orchardist 14(3):26-28.

Recasens, J.R., D.I. Recasens, and J. Barragan. 1988. Sprinkler irrigation to obtain a refreshing microclimate. Effect on fruit growth rates and quality of 'Jonee' and 'Golden Smoothee' apples. Acta Hort. 228:197-204.

Unrath, C.R. 1972. The quality of 'Red Delicious' apples as affected by overtree sprinkler irrigation. J. Amer. Soc. Hort. Sci. 97:55-58.

Unrath, C.R. 1975. Cool off for better apples. Amer. Fruit Grower 95(8):11-12.

Williams, K.M. 1993. Use of evaporative cooling for enhancing apple fruit quality. Good Fruit Grower August:23-27. 